\title{
The Economic Impact of Hop Stunt Viroid and Certified Clean Planting Materials
}

\author{
Trent J. Davis and Miguel I. Gómez \\ Charles H. Dyson School of Applied Economics and Management, Cornell \\ University, Ithaca, NY 14853
}

\author{
Scott J. Harper \\ Department of Plant Pathology, Washington State University, Pullman, \\ WA 99164
}

\section{Megan Twomey \\ Association for the Development of Hop Agronomy, Moxee, WA 98936 \\ Additional index words. clean plant, disease management, economics}

\begin{abstract}
Hop stunt viroid (HSVd) is one of the most important pathogens impacting hop production worldwide. It reduces yields, stunts growth, and is easily transmissible. HSVd can cause significant yield losses upward of $62 \%$ depending on the hop variety. This study uses a net present value (NPV) approach over a 6-year production cycle of one acre of hops to examine the potential economic impact of HSVd on aroma and alpha hop varieties. The estimated economic impact of HSVd ranges from about $\$ 432$ (for a $1 \%$ yield reduction) to $\$ 26,795$ (for a $62 \%$ yield reduction) per acre. Using the NPV approach the study then analyzes potential economic benefits of using certified diseasefree planting stock as a strategy to mitigate the risk of HSVd infection. If expected yield losses of aroma and alpha hops exceed $6 \%$ and $7 \%$, respectively, then the NPV of investing in certified clean planting stock is greater than that of the infected hops over the 6year production cycle. Complete removal and replanting of an entire acre of aroma and alpha hops with certified clean planting stock is economically beneficial once expected yield losses exceed $35 \%$ and $36 \%$, respectively. These findings are valuable for giving hop producers information to devise profit-maximizing planting strategies and to create incentives for extended usage of certified clean planting materials.
\end{abstract}

Hop stunt viroid (HSVd) is a subviral pathogen belonging to the genus Hostuviroid, family Pospiviroidae (Di Serio et al., 2021). Despite

Received for publication 26 May 2021. Accepted for publication 21 Aug. 2021.

Published online 25 October 2021.

Sincere appreciation is expressed to the Animal and Plant Health Inspection Service of the USDA for funding this research under the grant ECONOMIC STUDIES: AN ASSESSMENT OF PAST AND CURRENT EFFORTS, AN EVALUATION OF NEEDS, AND A ROADMAP FOR FUTURE ACTIONS NATIONAL CLEAN PLANT NETWORK (NCPN), agreement ID: AP18PPQS\&T00C065. Furthermore, we would like to express our gratitude to the National Clean Plant Network and the Association for the Development of Hop Agronomy for their support. We would also like to express our appreciation to Suzette P. Galinato and Peter R. Tozer of the IMPACT Center at Washington State University, whose enterprise budgets of hop production in the Pacific Northwest played an invaluable part in conducting this research. Finally, thank you to Ann George, Executive Director of the Hop Growers of America, for providing insightful information regarding industry standards pertaining to hop production and HSVd mitigation.

Animal \& Plant Health Inspection Service of the USDA Grant Number: AP18PPQS\&T00C065.

T.J.D. is the corresponding author. E-mail: tjd233@cornell.edu.

This is an open access article distributed under the CC BY-NC-ND license (https://creativecommons. org/licenses/by-nc-nd/4.0/). lacking a known vector species, it has a wide host range, including hops (Humulus sp.), fruitbearing trees and vines (including Malus, Prunus, Citrus and Vitis sp.), as well as flowering plants (Hibiscus sp.) (Marquez-Molins et al., 2021). In most hosts, infection is symptomless, but it has been reported to cause the eponymous hop stunt disease in hop, as well as cachexia in citrus, and fruit marking symptoms on some stonefruit (Marquez-Molins et al., 2021).

HSVd is one of the most significant viruslike pathogens of hop production, first reported in Japan, and more recently found in hop-producing areas in the United States (Eastwell and Nelson, 2007; Pethybridge et al., 2008) and Australia (Chambers et al., 2021). Symptoms of HSVd infection vary by hop cultivar, and can include shortening of internodes on the bine and lateral shoots, which can limit the ability of the bine to climb a string or wire. Leaf drooping has been reported in Japanese hop cultivars, while in the United States, chlorotic flecking has been reported (Eastwell and Sano, 2009). Most importantly for hop production and the brewing process, Kappagantu et al. (2017) found HSVd can cause dry cone yields to be significantly reduced in certain varieties of hops, with average yields of 'Glacier', 'Willamette', and 'Cascade' hops reduced by $62 \%, 34 \%$, and $14 \%$, respectively, over a 6-year timespan. The same study also reported reductions in $\alpha$ - and $\beta$-acid content of $\approx 40 \%$ (Kappagantu et al., 2017), which is significant as these acids are important bittering agents in the production of beer.

Given these impacts, HSVd management is a critical concern to hop producers. As there are no known insect vectors, spread occurs by introduction of HSVd-infected plants into an area, and plant-to-plant transmission by sap transfer through wounds or pruning cuts (Pethybridge et al., 2008). The efficacy of transmission has not been quantified, though given the prevalence of HSVd in both Japan and the United States, HSVd should be easily transmitted in the absence of appropriate management practices. Once present, there is no in-field cure, with plant removal being the only effective solution (Pethybridge et al., 2008).

The United States is the largest global producer of hops (Kubeš, 2021). From 2012 to 2019, hop acreage in the United States has increased $98.7 \%$, resulting in 58,877 acres dedicated to hops production (George, 2020). The majority of hops in the United States are grown in the Pacific Northwest (PNW) with Washington state (WA) being the nation's largest producer accounting for $72.5 \%$ of total hop production (George, 2020). Aroma varieties are the most commonly grown hops accounting for $75.4 \%$ of total acreage, whereas alpha varieties represent $24.6 \%$ of acreage in the country (George, 2020). In 2019, hop production in the United States grew by $4.7 \%$, while hop acreage increased 2.6\% (George, 2020). Hop production in 2019 resulted in a new yearly record of an estimated 113 million pounds being produced in the United States (George, 2020).

In 2004, HSVd was first identified in Washington state, with a total of $15 \%$ of plant samples tested found to be infected by this viroid (Eastwell and Nelson, 2007). A subsequent study (Kappagantu et al., 2017) found HSVd incidence had increased to $17 \%$ of samples tested, with in field incidence ranging from $6 \%$ to $72 \%$ depending on the hop variety. Given the economic importance of hop production in the PNW, it is vital producers take steps to mitigate the risk of HSVd, which after removal, is preventing the reintroduction of the pathogen through the use of viroidtested planting material. One such strategy is using plant stocks certified free of viroids like HSVd.

Certified-clean, virus-tested foundation plant stocks are essential to specialty crop production (Fuchs et al., 2021). Production, maintenance, and distribution of virus-tested foundation propagation material in the United States is supported by the National Clean Plant Network (NCPN), a part of the USDA's Animal and Plant Health Inspection Services (APHIS) in conjunction with USDA's Agriculture Research Service, and USDA's National Institute for Food and Agriculture (NCPN, 2020). In the United States, certified clean hop planting stock is produced and distributed by the Clean Plant Center Northwest (CPCNW), at Washington State University (WSU) in Prosser, WA (CPCNW, 2020). 
Hop cultivars are tested for the presence of economically important viruses and viroids, including HSVd (Fuchs et al., 2021), and maintained in contained conditions to prevent reinfection before being distributed to hop producers as ' $\mathrm{G} 1$ ' stock. Material from G1 planting stock can be established in increase fields as ' $G 2$ ', with further propagation resulting in 'G3' and even ' $\mathrm{G} 4$ ' plants that may be sold to growers.

Purchasing plant stock certified to be virus free by the CPCNW [certified clean planting stock (CPS)], reduces the risk of obtaining hop planting stock that is infected with a virus. Producers may be hesitant to adopt CPS as the initial investment of purchasing CPS is higher than using plant stock that is not certified free of viruses by the CPCNW. Although the startup costs may be higher for adopting CPS, the production cycle is the same.

In year 1 , a producer plants his/her hops and should expect to have no production. In year 2 , a producer receives roughly $80 \%$ of full production, assuming the plants are healthy and there are no significant events decreasing hop yields. From years 3 to 6 , a producer should assume $100 \%$ production. We assume after year 6 a producer will replant the entire crop. However, it is important to note some producers continue to use hop plants after year 6 for production.

Few studies have addressed the potential economic benefits of using CPS for specialty crops supported by the NCPN (Fuchs et al., 2021). Recent literature reviews summarizing (Fuchs et al., 2021; Yeh et al., 2019) the economic studies on virus-tested plant materials and specialty crops noted a distinct lack of research analyzing the potential economic benefits of CPS and hop production. In this study, we estimate the economic benefits of using CPS for hop production versus the potential economic impacts of HSVd on hop farmers in the PNW for both aroma and alpha hop varieties. Using a net present value (NPV) approach two main subjects were analyzed:

1. At what estimated yield loss does the economic benefits of using CPS outweigh those of using plant stock not certified free of viruses [noncertified clean planting stock (NCPS)] by the CPCNW that is infected with HSVd.

2. At what estimated yield loss does it become economically beneficial for a producer to replant one acre of hop with CPS.

Specifically, the NPV approach was used to estimate different yield losses for one acre of hops production because of HSVd infection and compare these NPVs to that of one acre of CPS hops without HSVd presence. This study is the first of its kind to analyze the potential economic benefits of using CPS for hop production as a way to mitigate the risk of HSVd.

\section{Materials and Methods}

Combining data from the Hop Growers of America (George, 2020), WSU Extension (Galinato and Tozer, 2016), the CPCNW, and information provided by current/former hop producers, models were developed to estimate the NPV of one acre of alpha (and aroma) hops over a 6-year production cycle. Using a similar methodology to that of Atallah et al. (2012) we compare the models estimating different levels of hop yield losses due to HSVdinfected NCPS, and compare the resulting NPV to the NPV of hops planted using CPS, which are free from any pests and/or viruses. We assume the farm is already established and does not need to purchase new land, machinery, or trellising materials. For this reason, we use only yearly operating costs obtained from the WSU enterprise budget.

\section{Economic cost assumptions}

Using base information on yearly operating costs of one acre of hops in WA obtained from Galinato and Tozer (2015) three separate operational costs are developed; planting year, maturing year, mature years (years 3-6 of the 6-year planting cycle). To account for the potential increase in yearly costs because of inflation, we use information from the CPI equaling $0.7 \%, 2.1 \%, 2.1 \%$, and $1.9 \%$, respectively, for years 2015 to 2018 . Because of the relative similarity of management practices we use the same operating cost estimates for both aroma and alpha hop varieties. Table 1 shows the assumed yearly operating costs of one acre of both NCPS and CPS hop plantings:

It is assumed in the planting year the producer does not need to purchase, nor reinstall, any trellising materials. The model assumes 889 hop bines per acre are planted. The cost of NCPS is estimated at $\$ 2.00 /$ bine, whereas CPS is estimated at $\$ 5.00 /$ bine. We estimate the operating costs of the first year (planting year) to equal $\$ 6933 /$ acre for NCPS and \$9548/acre for CPS when planting one acre. Planting one acre of CPS is estimated to cost $37.7 \%$ more than planting NCPS.

We assume after the initial decision to plant either CPS or NCPS is made, the yearly management practices are the same for the maturing year and mature year(s). In year 2, the maturing year, we estimate operating costs to equal $\$ 8159 /$ acre. For year 3 through 6 , mature years, we estimate yearly operating costs to equal $\$ 8475 /$ acre. It is important to note these estimates are developed using a benchmark study conducted in 2015 and updated using the CPI. Individual farms may have higher or lower yearly operating costs based on different hop managerial practices.

Table 1. Yearly operating costs of producing one acre of hops.

\begin{tabular}{lll}
\hline & $\mathrm{NCPS}^{\mathrm{z}}$ & $\mathrm{CPS}^{\mathrm{y}}$ \\
\hline Planting year (1) & $\$ 6,933$ & $\$ 9,548$ \\
Maturing year (2) & $\$ 8,159$ & $\$ 8,159$ \\
Mature years (3-6) & $\$ 8,475$ & $\$ 8,475$ \\
\hline${ }^{\mathrm{z}}$ NCPS represents noncertified clean planting stock. \\
${ }^{\mathrm{y}}$ CPS represents certified clean planting stock.
\end{tabular}

Yield and sales assumptions

Yield assumptions are assumed to be $0 \mathrm{lb} /$ acre in the planting year, $80 \%$ in the maturing year, and $100 \%$ during the mature years (years 3 through 6). In 2019, the average yield of aroma hops on a per-acre basis in the United States was $1981 \mathrm{lb} /$ acre (George, 2020). For simplicity, the model uses $2,000 \mathrm{lb} /$ acre as the base yield expectations for aroma hops. After consulting with representatives from the Hop Growers of America, we use an expected yield of $430 \mathrm{lb} /$ alpha per acre.

Aroma hops sold for an average of $\$ 5.68$ / lb in 2019 (George, 2020). The base model uses $\$ 5.80 / 1 \mathrm{~b}$ when calculating sales receipts. It is important to note the sales price is meant to represent a price similar to the 2019 market average. After consulting with representatives from the Hop Growers of America we assume a base sales price of $\$ 25 \mathrm{lb} / \mathrm{alph}$. No premium is added to using CPS hops. Table 2 shows the expected receipt amounts for the planting, maturing, and mature years for both aroma and alpha hops at full production.

\section{Economic analysis}

Various scenarios were constructed reflecting the cash flow of one acre over a 6-year planting cycle of both aroma and alpha hops (common planting cycle for hops in WA is between 5 to 7 years). The scenarios differ by the biological and managerial parameters. Biological parameters include NCPS hops with no prevalence of HSVd, HSVd-infected NCPS hops at various yield reduction levels, and CPS hops with no prevalence of HSVd. Management practices measure if, and if so at what level of incidence, a producer should replant their entire acre of hops in the first year of maturity (year 3) if they observed HSVd in the maturing year (year 2). The following scenarios were considered to measure the potential economic impact of using CPS to counter potential HSVd infection.

Scenario One: Baseline. The baseline scenario consists of a cash flow for one acre of NCPS hops over a 6-year planting cycle with no incidence of HSVd. The baseline scenario was used as a benchmark to estimate the economic impact of HSVd under the scenarios described below.

Scenario Two: CPS. This scenario simulated a situation where a producer invests in CPS hops. Because of using CPS hops this scenario assumes no HSVd incidence is present, so yields are always producing at the baseline level. The NPV of this scenario is compared with that of the baseline scenario and following scenarios estimating the economic impact of HSVd prevalence reducing estimated yields.

Scenario Three: HSVd presence scenarios. These scenarios correspond to situations

Table 2. Yearly sales receipts of producing one acre of hops.

\begin{tabular}{lcc}
\hline & Aroma hops & Alpha hops \\
\hline Planting year (1) & $\$ 0$ & $\$ 0$ \\
Maturing year (2) & $\$ 9,280 /$ acre & $\$ 8,600$ \\
Mature years $(3-6)$ & $\$ 11,600 /$ acre & $\$ 10,750$ \\
\hline
\end{tabular}


where HSVd is prevalent in the NCPS hops. Different levels of estimated yield reduction because of the presence of HSVd are measured against the baseline and CPS scenarios to estimate the potential economic loss due to $\mathrm{HSVd}$, and potential economic benefit of using CPS hops.

Scenario Four: Replanting. This scenario compares the NPV over a 6-year span where in year 3 the grower replants the entire acre of hops with CPS hops because of observing HSVd in year 2. Different estimated yield losses are modeled and compared with the NPV of the results of scenario three to see whether there is a yield loss threshold where it is economically beneficial to replant in year 3 and only have 2 years of full production without yield losses compared with 4 years of full production with yield losses due to HSVd. Figure 1 outlines the process described for scenario four compared with scenario three.

\section{Results}

Economic impact of HSVd

The economic impact of HSVd over the 6-year life span of one acre of aroma hops in

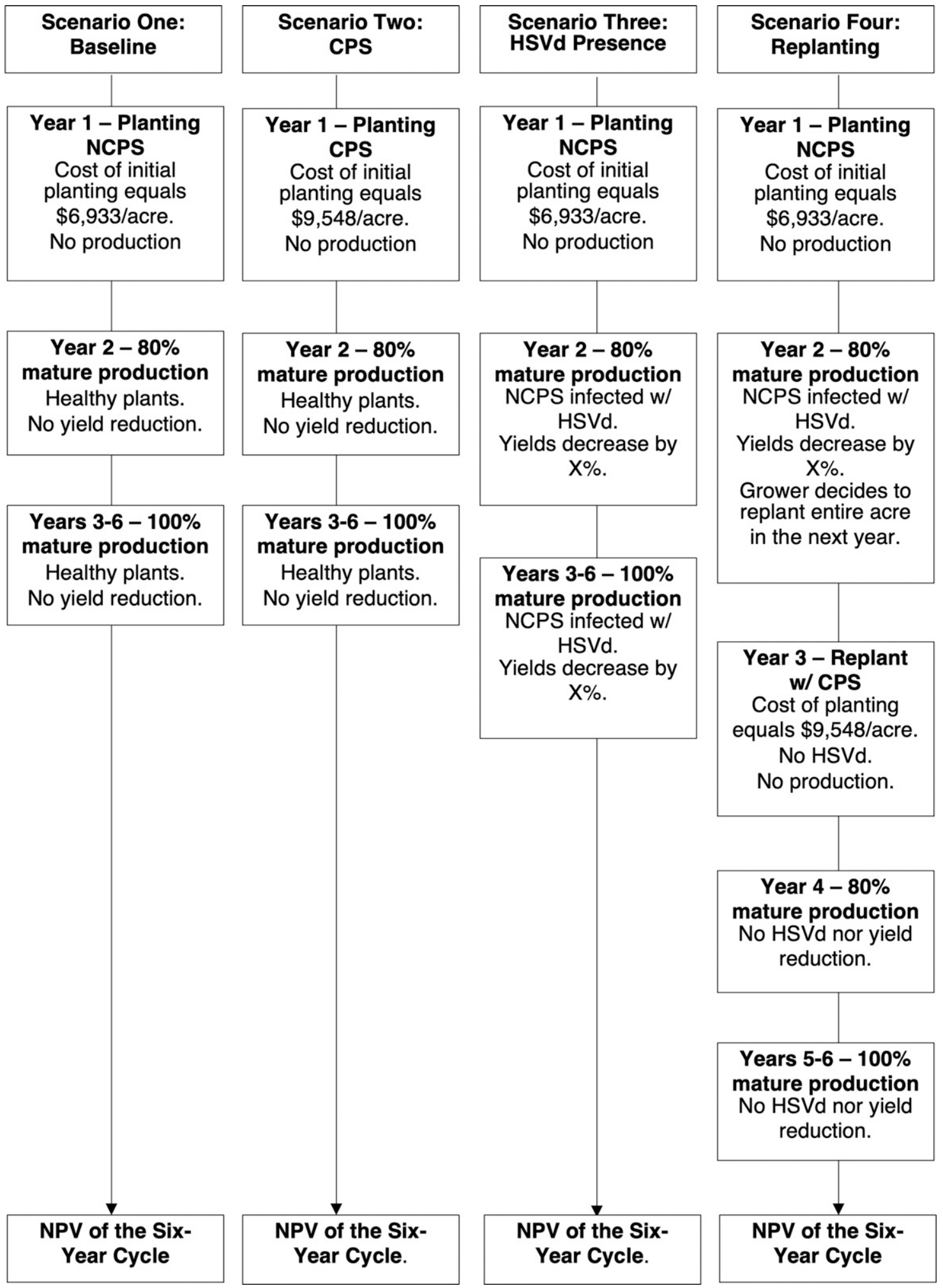

Fig. 1. Scenario four, when to replant with CPS. 
Table 3. NPV of one acre of NCPS-hops.

\begin{tabular}{lccc}
\hline Scenario & Estimated yield loss due to HSVd infection & Aroma hops NCPS & Alpha hops NCPS \\
\hline Baseline & $0 \%$ & $\$ 4,601$ & $\$ 1,435$ \\
3 & $5 \%$ & $\$ 2,441$ & $(\$ 568)$ \\
& $10 \%$ & $\$ 280$ & $(\$ 2,571)$ \\
& $15 \%$ & $(\$ 1,881)$ & $(\$ 4,573)$ \\
& $20 \%$ & $(\$ 4,042)$ & $(\$ 6,576)$ \\
\hline
\end{tabular}

$\mathrm{HSVd}=$ Hop stunt viroid $;$ NCPS $=$ noncertified clean planting stock.

WA ranges from $(\$ 26,795)$ acre (for $62 \%$ yield reduction without replanting in year 2) and $(\$ 432) /$ acre $(1 \%$ yield reduction without replanting in year 2). The economic impact of HSVd over the 6-year life span of one acre of alpha hops in WA ranges from $(\$ 24,831) /$ acre (for 62\% yield reduction without replanting in year 2) to (\$400)/acre (for $1 \%$ yield reduction without replanting in year 2).

The baseline scenario estimates the NPV of the 6-year planting cycle without HSVd and operating at full capacity for one acre of aroma and alpha hops are \$4601/acre and $\$ 1435 /$ acre, respectively. The results indicate for every $1 \%$ increase in expected yield losses because of HSVd the NPV of one acre of aroma and alpha hops decreases by $\$ 432$ / acre and $\$ 400 /$ acre, respectively. Table 3 shows the estimated NPVs for the baseline scenario and different levels of yield losses for the HSVd Presence Scenarios.

For aroma hops, we estimate the NPV remains positive up until yield losses exceed $10 \%$. Once losses for aroma hops exceed $10 \%$ the NPV of the 6-year cycle results in negative returns. For alpha hops, estimated yield losses of only $4 \%$ or greater result in a negative NPV for the 6-year planting cycle. These results are heavily dependent on the sales price used in the models. A higher sales price may result in a positive NPV at yield losses greater than $10 \%$ for aroma hops and $4 \%$ for alpha hops.

\section{Value of planting certified-clean planting stock}

The results indicate by paying the $150 \%$ price premium for CPS hops the NPV of one acre of aroma and alpha hops is \$2456/acre and \$2627/acre, respectively, less than the baseline scenario. The NPV of one acre of CPS aroma hops after the 6-year planting cycle equals \$2146/acre while one acre of CPS alpha hop equals (\$1021) over the same time span.

Table 4 demonstrates the potential economic benefits of investing in CPS hops compared with HSVd-infected NCPS hops. A positive number indicates the NPV of CPS plantings at full production without HSVd induced yield losses is higher by the indicated value than the NPV of HSVd-infected NCPS hops at the indicated yield loss.

The results indicate that even at minimal estimated yield losses the NPV of CPS is greater than that of NCPS. If a producer is expecting losses equal to or greater than $6 \%$ for aroma hops or $7 \%$ for alpha hops, then the NPV of planting CPS is greater than the NPV of the NCPS planting by \$137/acre and \$348/ acre, respectively. Once yield losses exceed $6 \%$ and $7 \%$ for aroma and alpha hops, respectively, for every $1 \%$ increase in expected losses the economic benefits of planting CPS increases by $\$ 432 /$ acre and $\$ 400 /$ acre.

\section{Economic benefits of replanting because of HSVd}

The results of scenario four indicate it takes a moderately high level of estimated yield losses because of HSVd to result in a greater NPV for replanting all hops with CPS in year 3 than continuing with the estimated yield losses for the entire planting cycle.

Aroma hops are shown to require 35\% yield losses or greater for replanting with CPS hops to have a greater NPV. At a 35\% yield loss the NPV of NCPs hops equals an economic loss of $\$ 10,525 /$ acre. If a producer is realizing 35\% yield losses of their NCPs hops and replants in year 3, the NPV of the replanted acre over the same 6-year time span equals an economic loss of \$10,465/acre, a \$60/acre improvement compared with not replanting.

Results are similar for alpha hop plantings. The results indicate an estimated $36 \%$ yield loss is required for alpha hops to result in the NPV of the replanting scenario being greater than not replanting. At 36\% estimated yield losses the NPV of the 6-year planting cycle is an economic loss of $\$ 12,984$ /acre while the NPV of replanting in year 3 with CPS results in an economic loss of $\$ 12,662$ / acre, a $\$ 322 /$ acre benefit.

Table 4. Potential economic benefits of certified CPS one acre of planted hops.

\begin{tabular}{lccc}
\hline Scenario & $\begin{array}{c}\text { Estimated yield loss } \\
\text { of noncertified } \\
\text { clean planting stock }\end{array}$ & $\begin{array}{c}\text { Aroma hops } \\
\text { Potential economic } \\
\text { benefits of CPS }\end{array}$ & $\begin{array}{c}\text { Alpha hops } \\
\text { Potential economic } \\
\text { benefits of CPS }\end{array}$ \\
\hline Baseline & $0 \%$ & $(\$ 2,456)$ & $(\$ 2,627)$ \\
3 & $5 \%$ & $(\$ 295)$ & $(\$ 453)$ \\
& $10 \%$ & $\$ 1,866$ & $\$ 1,549$ \\
& $15 \%$ & $\$ 4,027$ & $\$ 3,552$ \\
\hline
\end{tabular}

${ }^{\mathrm{z}}$ The NPV for CPS of aroma hops equals \$2146/acre.

${ }^{\mathrm{y}}$ CPS plantings are assumed to produce $100 \%$ of expected yields at all times.

${ }^{\mathrm{x}}$ The NPV for CPS of alpha hops equals (\$1021)/acre.

\section{Discussion}

Yeh et al. (2019) demonstrated the lack of research analyzing how growers of many specialty crops, like hops, may be able to use the NCPN to guard against different pests and pathogens. This is the first study researching the potential economic benefits of using certified, disease-free, clean planting stock for producing hops as a method to mitigate the risk of certain diseases.

HSVd viroid is easily transmissible and causes a damaging disease now endemic in North America (Pethybridge et al., 2008), which is impacting the revenues of hop farmers in the PNW. HSVd can result in hop yield losses of up to $62 \%$ in some varieties, with individual farmers reporting even higher yield losses exceeding 80\% (Kappagantu et al., 2017). The possible revenue losses due to yield reduction is a potential risk to hop farmers' livelihood.

HSVd commonly spreads to farms when farmers purchase HSVd-infected planting stock from third-party propagators (Eastwell, 2015). One way to mitigate this risk is to buy planting stock that has been virus-tested by organizations like the Clean Plant Center Northwest. While these CPSs have a greater upfront cost to farmers, the potential economic benefits they bring may outweigh the initial investment increase.

The results discussed above indicate that even a small yield loss because of HSVd suggests using CPS free of HSVd would result in higher returns. The net present value of a 6-year planting and production cycle of CPS is greater than that of NCPS of both aroma and alpha hop varieties if expected yield losses of the NCPS exceeds $6 \%$ and $7 \%$, respectively. HSVd may result in hop yields being reduced by $2 \%$ to $80 \%$ depending on the hop variety. The extreme variation of potential yield losses, and the relatively minimal yield losses necessary for the NPV of certified clean hops being higher over the 6year cycle indicates it may be economically advantageous for growers to pay the upfront premium of investing in certified clean plant stock to mitigate the risk of potential longterm losses because of HSVd.

Once HSVd is found on the farm, a producer should consider replanting all of the potentially infected bines with certified clean bines once yield losses are estimated to equal at least 35\% for aroma hops and 36\% for alpha hop varieties. This is a lower bound and may be too conservative as all costs for replanting, and safely eradicating HSVd, may not be included in our models. Future research should further examine this issue accounting for all costs of safely eradicating and replanting hops.

It is important to note the assumptions used in these models impact these results. If sales prices are higher than those used in the presented models, then the net economic benefits of using certified clean hop plantings, free from HSVd, increase relatively quickly. The models also assume the entire acre of NCPS plantings are infected with HSVd. While it is true the pathogen is easily spread through 
mechanical means it may not always be the case that an entire acre is infected with the pathogen. There is a current lack of research analyzing how quickly HSVd spreads through an acre (or more) of hop plants, which limits how we are able to model how an HSVd infection spreads, and thus, how the spread impacts yields. More research should be conducted regarding how quickly and easily HSVd can potentially spread from plant to plant. Furthermore, future models should take into account field locations with diverse environmental conditions and temperatures, both of which can impact the strength of HSVd symptoms. Our results show the economic benefits of planting CPS quickly outweigh the increased costs incurred by planting said hops.

\section{Literature Cited}

Atallah, S., M.I. Gómez, M.F. Fuchs, and T.E. Martinson. 2012. Economic impact of grapevine leafroll disease on Vitis vinifera cv. Cabernet franc in Finger Lakes vineyards of New York. Amer. J. Enol. Viticult. 63:73-79, https://doi. org/10.5344/ajev.2011.11055.

Chambers, G.A., K. Dodds, and N.J. Donovan. 2021. Hop stunt viroid detection in hops (Humulus lupulus) in Australia. Australas. Plant Dis. Notes 16(1):1-2, https://doi.org/10.1007/s13314-02100419-x.
CPCNW. 2020. About the Clean Plant Center Northwest. Clean Plant Center Northwest. 2 Dec. 2020. $<$ http://cpenw.wsu.edu/ $>$.

Di Serio, F., R.A. Owens, S. Li, J. Matoušek, V. Pallás, J.W. Randles, T. Sano, J. Th J Verhoeven, G. Vidalakis, and R. Flores. 2021. ICTV virus taxonomy profile. Pospiviroidae. J. General Virology 102(2), https://doi.org/https://doi. org/10.1099/jgv.0.001543.

Eastwell, K.C. and T. Sano. 2009. Hop stunt viroid, p. 48-51. In: W. Mahaffee, S. Pethybridge, and D.H. Gent (eds.). Compendium of hop diseases and pests. APS Press.

Eastwell, K. 2015. Managing hop stunt viroid, p. 40-41. In: D.B. Walsh, D.H. Gent, J.D. Barbour, R.A. Boydson, A.E. George, D.G. James, and J.R. Sirrine (eds.). Field guide for integrated pest management in hops. Hop Growers of America, Yakima, WA.

Eastwell, K.C. and M.E. Nelson. 2007. Occurrence of viroids in commercial hop (Humulus lupulus L.) production areas of Washington state. Plant Health Prog. 8:1, https://doi.org/10.1094/PHP2007-1127-01-RS

Fuchs, M., C.V. Almeyda, M. Al Rwahnih, S.S Atallah, E.J. Cieniewicz, K. Farrar, W.R. Foote, D.A. Golino, M.I. Gómez, S.J. Harper, and M.K. Kelly. 2021. Economic studies reinforce efforts to safeguard specialty crops in the United States. Plant Dis. 105(1):14-26, https:// doi.org/10.1094/PDIS-05-20-1061-FE.

Galinato, S.P. and P.R. Tozer. 2016. 2015 Estimated cost of establishing and producing hops in the Pacific northwest. Washington State University Extension, p. 1-9.
George, A. 2020. 2019 Statistical Report. Hop Growers of America. Hop Growers of America, Yakima, WA.

Kappagantu, M., M.E. Nelson, J.M. Bullock, S.T. Kenny, and K.C. Eastwell. 2017. Hop stunt viroid: Effects on vegetative growth and yield of hop cultivars, and its distribution in central Washington state. Plant Dis. 101:607-612, https://doi.org/10.1094/PDIS-06-16-0884-RE.

Kubeš, J. 2021. Geography of World Hop Production 1990-2019. J. Amer. Soc. Brew. Chem. 1-10, https://doi.org/10.1080/03610470.2021.1 880754.

Marquez-Molins, J., G. Gomez, and V. Pallas. 2021. Hop stunt viroid: A polyphagous pathogenic RNA that has shed light on viroid-host interactions. Mol. Plant Pathol. 22(2):153-162, https://doi.org/10.1111/mpp.13022.

National Clean Plant Network. 2020. About the National Clean Plant Network. 2 Dec. 2020. $<$ http://nationalcleanplantnetwork.org/about $>$.

Pethybridge, S.J., F.S. Hay, D.J. Barbara, K.C. Eastwell, and C.R. Wilson. 2008. Viruses and viroids infecting hop: Significance, epidemiology, and management. Plant Dis. 92:324-338, https://doi.org/10.1094/PDIS-92-3-0324.

Yeh, D.A., K. Park, M. Fuchs, and M.I. Gómez. 2019. A review of economic studies on pathogen-tested plant materials and clean plant programs for specialty crops. Charles H. Dyson School of Applied Economics \& Management, Cornell University, Ithaca, NY. <https://dyson. cornell.edu/wpcontent/uploads/sites/5/2020/ 02/Clean-plant-literature-review-FINAL-VD. pdf $>$. 